\title{
The Effect of Human Resource Management (HRM) Practices in Service-Oriented Organizational Citizenship Behaviour (OCB): Case of Telecommunications and Internet Service Providers in Malaysia
}

\author{
Thanigaivel R Krishnan ${ }^{1}$, Su Ann Liew ${ }^{1} \&$ Vui-Yee Koon ${ }^{1}$ \\ ${ }^{1}$ Sunway University, Malaysia \\ Correspondence: Thanigaivel R Krishnan, Sunway University, Malaysia. E-mail: thanigaivelkrishnan@gmail.com
}

Received: October 9, 2016

Accepted: November 20, 2016

Online Published: December 20, 2016

doi:10.5539/ass.v13n1p67

URL: http://dx.doi.org/10.5539/ass.v13n1p67

\begin{abstract}
In the human resource management-organizational performance research context, this paper is focusing on the effect of Human Resource Management (HRM) practices (pay practice, job security, training and development, supervisor support) on service-oriented Organizational Citizenship Behaviour (OCB) in Malaysian telecommunication and internet service providers. A quantitative study was conducted on 204 customer-contact employees who working in telecommunications and internet service providers in Malaysia. Correlation analysis and multiple regression analysis were applied to analyse the relationships between HRM practices and service-oriented OCB. The results indicate that, job security, training and development, supervisor support and overall perceptions of HRM practices have positive and significant effect on service-oriented OCB with the exception for pay practice.
\end{abstract}

Keywords: HRM Practices, Service-Oriented OCB, Customer-Contact Employees, Malaysia

\section{Introduction}

Service sector is one of the most important element in Malaysia economy growth and development (Central Bank of Malaysia, 2007; Department of Statistics Malaysia, 2013; Malaysian Industrial Development Authority, 2013; New Straits Times, 2015; The Star, 2014). Telecommunications and internet service providers in Malaysia are trying hard to offer better user experience but poor customer service from service providers are still remains a big problem for consumers.

Aizzat, Hazlina and Tan (2012) argued that scorecard evaluation by telecommunication and internet service providers to their customers are not helpful to improve the service quality. A report from Malaysian Communications and Multimedia Commission (MCMC) shows that majority of customer's complaints based on poor service from customer-contact employees (35\%), followed by service or product content (16.7\%), monthly bill and charging (13.9\%), SMS (10.1\%), no network coverage $(4.3 \%)$ and poor service coverage (3.5\%) (MCMC, 2013). The highest percentage of customer complaints due to poor service reflect the real situation of telecommunications and internet service provider's services in Malaysia. There is a significant gap between consumers expected and perceived service quality from Malaysian telecommunication and internet service providers.

To address this issue, service-oriented organizations have to analyse and develop their employee's service-oriented Organizational Citizenship Behaviours (OCB). According to Organ (1998), the employees who have the extra role behaviour could help to increase their organizational effectiveness and productivity. Generally, Organ, Podsakoff and Mackenzie (2006) defined OCB as employee's discretionary behaviour that go beyond their formal job requirements and descriptions which is not reimbursed by the reward system. Moreover, OCB is usually support to organizational performance and competitive advantage (Nemeth \& Staw, 1989). Besides that, Bateman and Organ (1983) stated that numerous studies were conducted widely to analyse OCB since it was introduced about twenty years ago.

Many previous empirical studies of OCB have focused on organizational performance and human resource strategies (Arthur, 1994; Snape \& Redman, 2010; Tsui, Pearce, Porter \& Tripoli, 1997). Besides that, several research studies also had conducted on organizational effectiveness and OCB (Bateman \& Organ, 1983; Podsakoff, MacKenzie, Moorman, \& Fetter, 1990; Walz \& Niehoff, 2000; Yen \& Niehoff, 2004). 
Besides that, past researches on OCB had focused only on the general form of organizational citizenship behaviour. In addition, only few studies had focused on specific forms of OCB personalised to a particular sector such as in a service sector. For instance, Bettencourt and Brown (1997) were conducted few studies on particular forms of OCB such as service-oriented organizational citizenship behaviours (service-oriented OCB) and studies show that limited guidance and attention have been given to specify organizational practices that elicit service-oriented OCB. The definition of Bettencourt and Brown (1997) on service-oriented OCB is discretionary behaviours of customer-contact employees in a service provider organization that go beyond formal job requirements.

In the case of Malaysia, past studies had conducted only on service-oriented OCB relate to the agricultural business, logistics industry, hospitality industries and public sector (Chaudhry \& Usman, 2011; Ladebo, 2004; Nasurdin, Ling, \& Fun, 2011; Sun, Aryee, \& Law, 2007). Thus, lack of study has been focused on developing customer-contact employee's service-oriented OCB in Malaysian telecommunications and internet service provider.

Besides that, there is limited studies on specific organizational practices that may influence OCB. This observation was made based on the way of an organization approach to Human Resource Management (HRM) practices that can lead to high levels of OCB (Morrison, 1996) and also the way of an organization manages its human resources to set the good conditions and high quality for the relationship between organization and employee (MacDuffie, 1995; Rousseau \& Greller, 1994).

Thus, HRM practices play an important role in the organizational success and operation. Moreover, HRM practices are one part of organizational-based resource that can support employees in reducing their job demands and the associated psychological and physiological costs, motivating their personal learning, growth and development achieving their job goals (Salanova, Agut, \& Peiro, 2005). Hence, there is a reason to conducts study on how the HRM practices help the organization manage their employees in achieving higher success and performance (Abdullah, Ahsan, \& Alam, 2009). Besides that, most of the past empirical studies found that HRM practices have positive significant effect on organizational performance and there is extensive evidence that systems of HRM practices are associated with different measures of organizational performance (Arthur, 1994; Appelbaum, Bailey, Berg, \& Kalleberg, 2000; Guthrie, 2001; MacDuffie, 1995; Wright, Gardner, Moynihan, \& Allen, 2003). However, there is only few studies described the processes through which HRM practices effect the primary intermediate variables that ultimately influence the performance of an organization (Becker, Huselid, Pickus, \& Spratt, 1997).

A review of past studies shows that HRM practices are major element in influencing positive OCB within the services sector (Liao et al., 2009; Tsaur \& Lin, 2004; Tang \& Tang, 2012). However, these studies have been only conducted in Japan, United States of America and Taiwan respectively. According to Paine and Organ (2000), and Turnipseed and Murkison (1993), national cultures have significant effects on the performance of OCB. Thus, given the differences in culture between Malaysia and other countries, findings by Sun et al. (2007) in other countries may not be generalizable to Malaysia. In the Malaysian context, majority of studies on HRM practices were focused on organizational-level outcomes (i.e. organizational performance) with less interested were given to individual-level outcomes (Daud \& Ahmad, 2003; Rose \& Kumar, 2006). Moreover, Wright et al. (2003) had investigated the relationship between HRM practices and organizational performance. The result of study shows that HRM practices affect the organizational performance through its influences of individual employee attitudes and behaviours (Wright et al., 2003).

Thus, there is still a great interest in finding further evidence about the linkages between HRM practices and service-oriented OCB. Based on the above discussion, the main objective of this research is to bridge the gaps by analysing the relationship between HRM practices and service-oriented OCB in the context of telecommunications and internet service providers in Malaysia.

\section{Literature Review}

Zerbe, Dobni and Harel (1998) is mentioned that the relationship between HRM practices and strategic outcomes is solidest in service organizations as opposed to manufacturing organizations. When employees get satisfied with their organization's HRM practices, employees are more likely to contribute their resources and energies for providing a good service to their customers (Schneider \& Bowen, 1985). This statement is consistent with Ogilvie (1986)'s perception of HRM practices which shows the level of concern that organization appears to have their employees. Employees are more willing to perform OCB's when organization's increased social exchange relationships with employees (Morrison, 1996).

HRM practices highly contribute on long-term relationships with employees through the delivery of continuous 
education and development programs, individualized orientation activities, promotion opportunities, supportive benefits and assurances of job security which more likely to lead to greater OCB's (Morrison, 1996). Besides that, Sun et al. (2007) argued that high performance HRM practices which include the delivery of extensive skills training, promotion and job security from within can collectively affect organizational level performance in terms of grouped service-oriented OCB over two means: (1) These practices indicate organization's target to create a long-term relationships with their employees; and (2) Represents the organization's encouragements that by creating employees' perception of a supportive work environment and satisfying employee goals. From a social exchange perspective (Blau, 1964), employees are mostly become grateful and motivated to respond with service-oriented OCB under these circumstances (Sun et al., 2007).

Based on previous studies arguments (Fiorito et al., 2007; Harel \& Tzafrir, 1999; Sun et al., 2007; Whitener, 2001; Zerbe et al., 1998), it is predicted that what constitutes greatest HRM practices will be significantly related to employees' service-oriented OCB. Thus, the selection of HRM practices in this research are mainly based on ERG's theory of motivation. According to Alderfer (1972), ERG theory is conceptualized three elements of human needs (existence, relatedness, growth) that employees attempt to satisfy in their organizations. Thus, salary or monetary rewards are categorised as employee's physiological needs for existence; job security is categorised as employee's safety needs for existence; training and development is categorised as employee's needs for growth and supervisor support is categorised as employee's need for relatedness in the organization. Therefore, in this research proposed four HRM practices (training and development; pay practice; job security and supervisor support) based on ERG's theory of motivation that may foster greater levels of service-oriented OCB.

\subsection{Pay Practice}

According to Parker and Wright (2001), money has the potential to influence employee's attitude and behaviour. Pay practice generally refers to a reward system including basic salary, performance pay and allowances that organization paid for their employees (Byars \& Rue, 2004). The HRM of organizations were paid differently for the same job to certain employees based on employee's individual differences in responsibility, working experience, job performance, education qualification and as well as seniority of employee (Bateman \& Snell, 2007; Cherrington, 1995).

Appropriate pay practice in the organization may develop employees to increase their performance, motivation and productivity (Milgrom \& Roberts, 1992). The use of an appropriate pay practice in organization suggest that employee's capabilities, performance and effort contributions are appreciated and recognized (Chew \& Chan 2008; Davies, 2001). Hence, this could lead to higher commitment and satisfaction amongst employees. According to expectancy theory (Vroom, 1964), when employees received a satisfied pay, they more likely to increase their contribution in working hard to increase the OCB of individual which will lead to improve the service quality of the organization. Past study based on expectancy theory shows that pay practice positively influences employee's OCB (Van Scotter, 2000). According to Konovsky and Pugh (1994), OCB is a positive behaviour of an employee to the organization and pay practice will have positive influence on OCB as well as job involvement in an organization. Besides that, other past studies on OCB found that pay practice is significantly affect employee's OCB in organization (Frye, 2004; Huselid, 1995; Teseema \& Soeters, 2006).

In addition, pay practice based on performance and allowances will further increase employee performance (Brown, Sturman \& Simmering, 2003; Delaney \& Huselid, 1996). Collins and Clark (2003) stated that most of the organizations used performance and allowance based pay practice to reward employees and it's positively effects employee's OCB. Thus, pay practice makes employees well motivated to go further their call of job responsibilities in the form of higher service-oriented OCB. Hence, the following hypothesis is proposed:

Hypothesis 1: Employees' pay practice will be significantly effect on service-oriented OCB.

\subsection{Job Security}

Job security is the degree of an employee expects to stay or work in the organization for a longer period of time (Delery \& Doty, 1996). Besides that, Simon (2011) stated that job security influences the probability of employee keeping his or her job without the risk of becoming unemployed. Furthermore, necessary or essential skills, job knowledge, and past working experience needed by the organizations; and subject to the current business environment and current economic condition also secure employee's job security (Pfeffer, 1998).

Employees have time to focus on the tasks at hand and getting their job done perfectly when employees feel their jobs are secure. Job security has a positive influence with employee performance in an organization (James, 2012). According to James (2012), employees with low job security are losing faith with their organization 
which consequently affects their performance in an organization. Thus, employees with high job security are highly contribute themselves in the job to perform their task effectively. Job security reduces employees' risk of job sacking during an economic crisis and creates a good relationship of trust between employees and the organization.

Several past studies have been conducted on determining the relationship between job security and OCB (Eatough, Chang, Miloslavic \& Johnson, 2010; Feather \& Rauter, 2004; Gong \& Chang, 2008; König, Debus, Häusler, Lendenmann \& Kleinmannet, 2010; Reisel, Probst, Chia, Maloles, \& König, 2010; Staufenbiel \& König 2010; Wong, Wong, Ngo \& Lui, 2005). The previous studies show that low job security was impact employee's mental and physical health and employee's attitude and behaviour negatively such as lowered OCB (Ashford, Lee \& Bobko, 1989; Kopp, Stauder, Purebl, Janszky, \& Skrabski, 2007; Laszlo et al., 2010). Besides that, a past study results shows that high job security significantly affects employee's performance of OCB (De Witte, 1999). Furthermore, Reisel et al. (2010) showed job security build a positive relationship between employee and employer. Thus, job stability ensures employees' sense of responsibility and attachment to the employer which is critical for the showing of Service-Oriented OCB (Sun \& Pan, 2008). Hence, the following hypothesis is proposed:

Hypothesis 2: Employees' job security will be significantly effect on service-oriented OCB

\subsection{Training and Development}

Training and development practices of an organization indicates forms of human capital investment for organizational and employees improvements (Wentland, 2003). The study from U.S. Department of Labor (1993) shows that training and development practices have been shown to be significant elements of efficient performance in the organization (Terpstra \& Rozell, 1993). The previous study from Russia proved that training and development opportunities gives an organization the competitive advantage (Jukov \& Korotov, 1998; Shekshnia, 1998). According to Dessler (2008), training and development practices are developing employee's skills and abilities to perform well on their job in organization. Hence, the results from previous researches shows that training and development programs positively influence employee's performance in organization (Delaney \& Huselid, 1996; Koch \& McGrath, 1996). Besides that, providing training and development programs are influence employees to receive necessary skills, knowledge and attitudes to function responsibly (Guest, 2000). Thus, employees who have attend more training and development programs are likely to perform better.

Several past studies have been conducted on the influences of training and development on employee's attitude and behaviour and the results indicate that training and development positively influence the employee's OCB in an organization (Ashill, Carruthers \& Krisjanous, 2006; Tsaur \& Lin, 2004; Tang \& Tang, 2012). Besides that, a study from Aizzat et al. (2012) explained that customer-contact employees are expected to become highly motivate and willing to involve themselves in service-oriented behaviours that exceed their formal job through training and development. Thus, training and development would develop greater service-oriented OCB amongst employees. Another past studies show that, training and development program help new employees adapt themselves to early entry experiences resulting in lower feeling of uncertainty (Autry \& Wheeler, 2005; Simosi, 2010; Van Maanen \& Schein, 1979). In such situation, new employees are more interested to become committed to the work which makes them to engage in behaviour such as service-oriented OCB. Hence, the following hypothesis is proposed:

Hypothesis 3: Employees' training and development will be significantly effect on service-oriented OCB.

\subsection{Supervisor Support}

According to Griffin, Patterson \& West (2001), supervisor support is defined as the extent of supervisors care about their employee's well-being and values their employee's contribution in the organization. Supervisor is a representative of the organization that have responsibility to guide and evaluate performance of the employees (Eisenberger, Stinglehaumber, Vandenberghe, Sucharski \& Rhoades, 2002). Moreover, employees perceived the care that received from supervisors and they make common perceptions on the amount of their organizations gives value to their contributions and also take care of their benefits and well-being (Eisenberger, Huntington \& Huchison, 1986). The strength of the relationship is also dependent on which level employees perceived the relation with their supervisor (Eisenberger et al., 2002).

Past studies found that supervisor support from the supervisor can develop employee's good perception of the organization and acceptance of the organization's values and goals among employees (Rhoades, Eisenberger, \& Armeli, 2001). Besides that, a past study results shows that higher supervisor support can improve employee's performance of OCB in the organization (Podsakoff, MacKenzie, Paine, \& Bachrach, 2000). The results were 
explained that leader member exchange influenced trust of employees significantly and improved perceived supervisor support within employees. This makes employees to perform greater OCB in their organization. Furthermore, Mayer and Gavin (2005) showed that employee's trust with supervisor build a positive relationship amongst employees. Thus, these lead employees commit more to their organizations and more likely to feel satisfied which in turn lead to greater service-oriented OCB. Hence, the following hypothesis is proposed:

Hypothesis 4: Employees' supervisor support will be significantly effect on service-oriented OCB.

\subsection{Overall HRM Practices}

Previous literatures linking HRM practices to employee's attitude and behaviour suggested that an integrated set or overall perception of HRM practices has a greater effect on performance rather than HRM practices taken individually (Dyer \& Reeves, 1995; Koon, 2014; Ramsay, Scholarios, \& Harley, 2000). On the basis of the preceding discussion and from the perspective of social exchange (Blau, 1964), it can be expected that customer-contact employees' overall perceptions of their telecommunications and internet service provider's HRM practices (training and development, pay practice, job security, supervisor support) will significantly and positively affect their service-oriented OCB. Hence, the following hypothesis is proposed:

Hypothesis 5: Employees' overall perception of HRM practices will be significantly effect on service-oriented OCB.

\section{Methodology}

The main objective of this research is to determine the relationship between HRM practices and service-oriented OCB. The unit of analysis for this study is at the individual level, which is the customer-contact employee that working in telecommunication and internet service providers in Malaysia. Simple random sampling method was used to select respondents for this study. Simple random sampling was used in this research in order to avoid bias and to ensure that each customer-contact employee working in telecommunications and internet service providers had an equal chance of being selected. In total 204 completed questionnaires were collected from target respondents and a response rate is $81.60 \%$. Self-administered questionnaire was used as an instrument for data collection in this study. Werner and Eleanor (1993) suggested that self-administered questionnaire that distributed by hand is most suitable method of data collection in a research.

A quantitative descriptive survey method was used in this research. The questionnaire was categorised into Section A and Section B. Thus, Section A consists of target questions and Section B consists of age, gender, marital status, nationality, race, religion, education level, monthly income and working experience. All items used in the questionnaire were based on a five-point Likert scale ranged from "Strongly Disagree" with the value of one to "Strongly Agree" with the value of five in this study.

In this research, the questionnaires for HRM practices and service-oriented OCB were adapted from past studies and the questionnaires used in the previous literatures have been found to be reliable and valid (Bettencourt, Meuter, \& Gwinner, 2001; Chen \& Huang, 2009; Cummings \& Oldham, 1997; Zeytinoglu, Denton, Davies, \& Plenderleith Millen, 2009; Hammer, Kossek, Yragui, \& Bodneret, 2009; Manafi, Hojabri, \& Aghapour, 2012; Mikander, 2010; Shahzad, Bashir, \& Ramay, 2008; Wick \& Leon, 1993; Yeh, 2013).

The collected data were analysed using the computerized Statistical Package for Social Sciences (SPSS) software (Buglear, 2005). Preliminary analyses were conducted to test the goodness of data and regression statistical analysis was conducted to test the hypotheses for this research (Sekaran, 2011). The factor analysis was conducted to address the problem of analysing the structure of the interrelationship among a large number of variables. Besides that, Cronbach's alpha was calculated to measure reliability scale for each variable which indicate how consistent the responses were across items within the scale. Correlation analysis was conducted to examine the relationship between HRM Practices and service-oriented OCB. Furthermore, regression analysis was applied to analyse the effect of HRM practices on service-oriented OCB.

\section{Findings and Discussion}

\subsection{Demographic Characteristics}

Total 204 Malaysian respondents were included in this study. Table 1 shows the frequency and percentage of each group related to demographic factors. 
Table 1. Profile of Respondents

\begin{tabular}{|c|c|c|c|}
\hline Demographic & Categories & Frequency & Percentage (\%) \\
\hline \multirow[t]{5}{*}{ Age } & Under 21 & 66 & 32.4 \\
\hline & 21 to 34 & 101 & 49.5 \\
\hline & 35 to 44 & 37 & 18.1 \\
\hline & 45 to 54 & 0 & 0.0 \\
\hline & 55 or Older & 0 & 0.0 \\
\hline \multirow[t]{2}{*}{ Gender } & Male & 129 & 63.2 \\
\hline & Female & 75 & 36.8 \\
\hline \multirow[t]{4}{*}{ Marital Status } & Single & 125 & 61.3 \\
\hline & Married & 78 & 38.2 \\
\hline & Divorced & 1 & 0.5 \\
\hline & Widowed & 0 & 0.0 \\
\hline \multirow[t]{2}{*}{ Nationality } & Malaysian & 204 & 100.0 \\
\hline & International & 0 & 0.0 \\
\hline \multirow[t]{4}{*}{ Race } & Malay & 70 & 34.3 \\
\hline & Chinese & 86 & 42.2 \\
\hline & Indian & 47 & 23.0 \\
\hline & Others & 1 & 0.5 \\
\hline \multirow[t]{5}{*}{ Religion } & Muslim & 70 & 34.3 \\
\hline & Buddhist & 38 & 18.6 \\
\hline & Hindu & 42 & 20.6 \\
\hline & Christian & 53 & 26.0 \\
\hline & Others & 1 & 0.5 \\
\hline \multirow[t]{5}{*}{ Education Level } & SPM/STPM & 59 & 28.9 \\
\hline & Diploma & 66 & 32.4 \\
\hline & Undergraduate Degree & 79 & 38.7 \\
\hline & Postgraduate Degree & 0 & 0.0 \\
\hline & Others & 0 & 0.0 \\
\hline \multirow[t]{4}{*}{ Monthly Income } & RM1999 and Below & 69 & 33.8 \\
\hline & RM2000 to RM2999 & 99 & 48.5 \\
\hline & RM3000 to RM4999 & 36 & 17.6 \\
\hline & RM5000 and Above & 0 & 0.0 \\
\hline \multirow[t]{5}{*}{ Working Experience } & One year to less than two years & 70 & 34.3 \\
\hline & Two years to less than three years & 93 & 45.6 \\
\hline & Three years to less than five years & 40 & 19.6 \\
\hline & Five years to less than ten years & 1 & 0.5 \\
\hline & Ten years or more & 0 & 0.0 \\
\hline
\end{tabular}

\subsection{Preliminary Analysis}

\subsubsection{Factor Analysis}

Factor analysis is used to organise the concealed structure within the collected respondents and to arrange the number of indicators into a more well-organised and manageable set of data (Harman, 1976). In this study, two factor analyses as shown in Table 2 were conducted to verify the hypothesized dimensionality of the independent and dependent variables respectively. In factor analysis, a forced choice procedure was chosen for the number of extracted factors with VARIMAX rotation. The results of this research show that the KMO (Kaiser-Meyer-Olkin) value for all variable are above 0.5. Furthermore, Bartlett's test of sphericity was significant for all variables of this study. Besides that, all variables of this this study had Eigenvalues more than 1. Primary factor loading for each item in a variable is required to have minimum 0.4 and above (Coakes and Steed, 2003). In this study, the items for each variable had primary factor loadings of 0.4 and above, and proved that it met the acceptable standard of factor analysis. The minimum acceptance criteria of reliability are the Cronbach's alpha value must 
be more than 0.6 (Sekaran, 2011). In this study, the result of reliability analysis indicated that the value of Cronbach alpha of each variable met the acceptable standard of reliability analysis. All the variable's Cronbach alpha of this study fall between 0.93 and 0.97 .

Table 2. Factor Analysis

\begin{tabular}{|c|c|c|c|c|c|c|c|}
\hline Measure & Items & $\begin{array}{l}\text { Factor } \\
\text { Loading }\end{array}$ & $\mathrm{KMO}$ & $\begin{array}{l}\text { Bartlett's Test } \\
\text { of Sphericity }\end{array}$ & Eigenvalue & $\begin{array}{l}\text { Variance } \\
\text { Explained }\end{array}$ & $\begin{array}{c}\text { Cronbach } \\
\text { Alpha }\end{array}$ \\
\hline \multicolumn{8}{|c|}{ Independent Variable } \\
\hline Pay Practice & 14 & $\begin{array}{c}0.58 \text { to } \\
0.75\end{array}$ & 0.946 & $8495.65^{*}$ & 7.70 & 18.32 & 0.95 \\
\hline Job Security & 8 & $\begin{array}{c}0.66 \text { to } \\
0.76\end{array}$ & 0.946 & $8495.65^{*}$ & 5.53 & 13.17 & 0.93 \\
\hline $\begin{array}{l}\text { Training and } \\
\text { Development }\end{array}$ & 11 & $\begin{array}{c}0.78 \text { to } \\
0.83\end{array}$ & 0.946 & $8495.65^{*}$ & 8.71 & 20.73 & 0.97 \\
\hline Supervisor Support & 9 & $\begin{array}{c}0.67 \text { to } \\
0.77\end{array}$ & 0.946 & $8495.65^{*}$ & 6.44 & 15.33 & 0.94 \\
\hline \multicolumn{8}{|c|}{ Dependent Variable } \\
\hline $\begin{array}{c}\text { Service-Oriented } \\
\text { OCB }\end{array}$ & 16 & $\begin{array}{c}0.76 \text { to } \\
0.86\end{array}$ & 0.941 & $3105.56^{*}$ & 10.30 & 64.39 & 0.96 \\
\hline
\end{tabular}

Note. $*$ Significant at the 0.0001 level

\subsubsection{Correlation Analysis}

Table 3 is shows that Means, Standard Deviation (SD) and Bivariate Correlations of the variables. According to Sekaran (2011), the bivariate correlations is a statistical method that used to determine the relationship between independent variables and dependent variable. Correlation analysis used in this study to determine relationship between HRM practices (pay practice, job security, training and development, supervisor support) and service-oriented OCB. The results in Table 3 show that correlation between pay practice $\left(r_{1}=0.61\right)$, job security $\left(r_{2}=0.64\right)$, training and development $\left(r_{3}=0.65\right)$ and supervisor support $\left(r_{4}=0.60\right)$ are significant for the service-oriented OCB.

Table 3. Means, Standard Deviations (SD) and Bivariate Correlations

\begin{tabular}{llllllll}
\hline Variables & Mean & SD & 1 & 2 & 3 & 4 & 5 \\
\hline Pay Practice (1) & 3.34 & 0.90 & 1 & & & & \\
Job Security (2) & 3.49 & 0.87 & $0.69^{* *}$ & 1 & & & \\
Training and Development (3) & 3.00 & 1.06 & $0.62^{* *}$ & $0.49^{* *}$ & 1 & & \\
Supervisor Support (4) & 3.69 & 0.87 & $0.63^{* *}$ & $0.57^{* *}$ & $0.54^{* *}$ & 1 & \\
Service-Oriented OCB (5) & 3.58 & 0.86 & $0.61^{* *}$ & $0.64^{* *}$ & $0.65^{* *}$ & $0.60^{* *}$ & 1 \\
\hline
\end{tabular}

Note. $* *$ Correlation is significant at the 0.01 level (2-tailed)

\subsection{Hypotheses Testing}

The regression analysis was used to determine the effect of HRM practices (pay practice, job security, training and development, supervisor support) and perception of overall HRM practices on service-oriented OCB. Table 4 shows that the HRM practices statistically predict the service-oriented $\mathrm{OCB}, \mathrm{F}(4,199)=69.67, p<0.01$ and perception of overall HRM practices also statistically predict the service-oriented OCB, $\mathrm{F}(1,202)=251.55$, $p<0.01$. Coefficient correlation ( $\mathrm{R}$ value) for this models are 0.76 and 0.75 . These values show that HRM practices and overall HRM practices has positive relationship with service-oriented OCB. The $\mathrm{R}^{2}$ values indicate HRM practices can explain 58\% (0.58) and overall HRM practices can explain 56\% (0.56) of variations in the service-oriented OCB. This shows that both of these regression models are good fit for the data. The regression results in Table 4 show that of the five hypothesized relationships, four (job security, training and development, supervisor support) are significant $(p<0.05)$ and one (pay practice) is non-significant $(p>0.05)$.

Firstly, Hypothesis 1 suggests that employees' pay practice will be significantly effect on service-oriented OCB. 
However, the regression results show that non-significant effect with service-oriented OCB $(t=0.54, p=0.59)$. This study is counter to early study by Chew and Chan (2008); Davies (2001); and Parker and Wright (2000). Thus, this result shows that further analysis is needed to determine the potential moderating and mediating factors that effects the direct relationship between pay practice and service-oriented OCB.

Secondly, Hypothesis 2 suggests that employees' job security will be significantly effect on service-oriented OCB. The regression results for job security are significantly support the relationship with service-oriented OCB $(t=5.09, p<0.01)$. This finding is consistent with the previous studies by (Pfeffer, 1998; Sun \& Pan, 2008) that found job security has a positive significant effect with service-oriented OCB.

Next, Hypothesis 3 suggests that employees' training and development will be significantly effect on service-oriented OCB. The regression results for training and development have support this hypothesis $(t=6.09$, $p<0.01)$. This finding is consistent with past studies indicating that training and development programs provided by the organization were increased the employee's performance. In other word, training and development program is important for service-oriented OCB (Ashill et al., 2006; Tang \& Tang, 2012).

Fourth, Hypothesis 4 suggests that employees' supervisor support will be significantly effect on service-oriented OCB. The regression results indicate a positive significant relationship between supervisor support and service-oriented OCB in this study $(t=2.88, p<0.01)$. Based on this finding, previous literature also has consistently shown that supervisor support has a positive and significant effects on service-oriented OCB (Griffin et al., 2001; Rhoades et al., 2001).

Lastly, Hypothesis 5 suggests that employees' overall perception of HRM practices will be significantly effect on service-oriented OCB. In line with the results of past studies, the results of this study show that overall perception of HRM practices has a positive and significant effects on service-oriented OCB (Dyer \& Reeves, 1995; Ramsay et al., 2000). The regression results for overall perception of HRM practices have supported in this study $(t=15.86, p<0.01)$.

Table 4. Multiple Regression Analysis

\begin{tabular}{|c|c|c|c|c|c|c|}
\hline \multirow{2}{*}{ Model } & \multicolumn{2}{|c|}{ Unstandardized Coefficients } & \multirow{2}{*}{$t$} & \multirow{2}{*}{$F$} & \multirow{2}{*}{$R$} & \multirow{2}{*}{$R^{2}$} \\
\hline & $\mathrm{B}$ & s.e. & & & & \\
\hline Constant & 0.73 & 0.19 & $3.86^{*}$ & \multirow{5}{*}{$69.67(4,199)$} & \multirow{5}{*}{0.76} & \multirow{5}{*}{0.58} \\
\hline Pay Practice & 0.04 & 0.07 & 0.54 & & & \\
\hline Job Security & 0.33 & 0.07 & $5.09 *$ & & & \\
\hline Training and Development & 0.30 & 0.05 & $6.09 *$ & & & \\
\hline Supervisor Support & 0.18 & 0.06 & $2.88^{*}$ & & & \\
\hline Constant & 0.79 & 0.18 & $4.40^{*}$ & \multirow{2}{*}{$251.55(1,202)$} & \multirow{2}{*}{0.75} & \multirow{2}{*}{0.56} \\
\hline Overall HRM Practices & 0.83 & 0.05 & $15.86^{*}$ & & & \\
\hline
\end{tabular}

Note. ${ }^{*} p<0.01 ;$ s.e. $=$ standard error

Based on the statistical analysis above, the supported and not supported proposed hypotheses of this study are shown in Table 5.

Table 5. Results of the Analyses

\begin{tabular}{lll}
\hline Hypothesis & Statement of Hypothesis & Results \\
\hline H1 & Employees' pay practice will be significantly effect on service-oriented OCB. & $\begin{array}{l}\text { Not } \\
\text { Supported }\end{array}$ \\
H2 & $\begin{array}{l}\text { Employees' job security will be significantly effect on service-oriented OCB. } \\
\text { Employees' training and development will be significantly effect on } \\
\text { H3 }\end{array}$ & $\begin{array}{l}\text { Supported } \\
\text { service-oriented OCB. }\end{array}$ \\
H4 & $\begin{array}{l}\text { Employees' supervisor support will be significantly effect on service-oriented } \\
\text { OCB. }\end{array}$ & Supported \\
H5 & $\begin{array}{l}\text { Employees' overall perception of HRM practices will be significantly effect on } \\
\text { service-oriented OCB. }\end{array}$ & Supported \\
\hline
\end{tabular}




\section{Implications}

This research can help the service-oriented management by providing additional information about the influences of HRM practices toward service-oriented OCB. Thus, the results of this study could be a determinant to service-oriented organizations making more reliable decisions on the planning process in HRM matters in their organizations.

First, this study shows that pay practice has non-significant effect on employee's service-oriented OCB. However, the previous findings indicate that pay practice has a positive significant impact on the employee's performance (Chew \& Chan, 2008; Davies, 2001; Parker \& Wright, 2000). The finding of this study for pay practice indicates that non-consistent results with previous studies. Thus, further investigation is needed to determine the potential moderating and mediating factors that effects the direct relationship between pay practice and service-oriented OCB.

Second, this study shows that employee's job security has a positive significant effect on employee's service-oriented OCB. The managements of telecommunication and internet service provider should have agreement with customer-contact employees regarding employment contract. An employment contract is defined as written legal document that described about terms and conditions of an employment relationship between organization and employee (Susan, 2016). The organization should clearly have described about employee's job protection in employment contract. Thus, this could help customer-contact employees to stay longer period and perform well on their service-oriented OCB in organization.

Third, this study also shows that training and development has a positive significant effect on employee's service-oriented OCB. The management should conduct adequate pre-training to their new customer-contact employees on how to perform well good service to their customers in order to increase employee's service-oriented OCB.

Fourth, supervisor support in this study also shows positive effect on employee's service-oriented OCB. Thus, the management should implement awareness program to supervisors regarding employee's cares. This could help supervisors to improve themselves to care and value their customer-contact employee's contributions. Hence, supervisor support from the supervisor can develop employee's good perception of the organization and enhance employee's performance of service-oriented OCB.

Lastly, one of the major implication in this study is overall perception of HRM practices on employee's service-oriented OCB. The overall HRM practices positively influence employee's service-oriented OCB in this study. Thus, Ministry of Human Resources (MOHR) and other Malaysian government agencies should build better awareness of the benefits of HRM practices to motivate higher rate of retention of the customer-contact employees in the telecommunication and internet's service organizations. The awareness can be done by having induction and seminar sessions on benefit of HRM practices to allow telecommunications and internet service providers to evaluate their customer-contact employee's service-oriented OCB.

\section{Conclusion}

Based on the results of this research, three HRM practices (training and development, job security, supervisor support) did have positive effect towards employee's service-oriented OCB with the exception for pay practice variable. The pay practice on this study will not likely to influence the employee's service-oriented OCB in Malaysian telecommunications and internet service providers. The results for pay practice suggest to conduct further analysis to determine the potential moderating and mediating factors that effects the direct relationship between pay practice and service-oriented OCB. Finally, the overall perception of HRM practices in this study shows that HRM practices positively influence customer-contact employee's service-oriented OCB. From the results of this study, it can be concluded that objective of this study was achieved, which is to study about the influence of HRM practices on service-oriented OCB in the context of telecommunication and internet service providers in Malaysia.

\section{References}

Abdullah, Z., Ahsan, N., \& Alam, S. S. (2009). The effect of human resource management practices on business performance among private companies in Malaysia. International Journal of Business and Management, 4(6), 65-72. http://dx.doi.org/10.5539/ijbm.v4n6p65

Aizzat, M. N., N. Hazlina, A., \& Tan, C. L. (2012). Human Resource Management Practices, Service Climate and Service-Oriented Organizational Citizenship Behavior: A Review and Proposed Model. International Business Management, 6(4), 541-551. http://dx.doi.org/10.3923/ibm.2012.541.551 
Alderfer, C. P. (1972). Existence, relatedness, and growth. New York: Free Press.

Appelbaum, E., Bailey, T., Berg, P., \& Kalleberg, A. (2000). Manufacturing Advantage: Why High-Performance Work Systems Pay Off. Ithaca, NY: Cornell University Press.

Arthur, J. (1994). Effects of Human Resource Systems on Manufacturing Performance and Turnover. Academy of Management Journal, 37(4), 670-687. http://dx.doi.org/10.2307/256705

Ashford, S. J., Lee, C., \& Bobko, P. (1989). Content, causes, and consequences of job insecurity: A theory-based measure and substantive test. Academy of Management Journal, 32(4), 803-829. http://dx.doi.org/10.2307/256569

Ashill, N., Carruthers, J., \& Krisjanous, J. (2006). The effect of management commitment to service quality on frontline employees' affective and performance outcomes: An empirical investigation of the New Zealand public healthcare sector. International Journal of Non-profit and Voluntary Sector Marketing, 11(4), 271-287. http://dx.doi.org/10.1002/nvsm.281

Autry, C. W., \& Wheeler, A. R. (2005). Post-hire human resource management practices and person-organization fit: A study of blue-collar employees. Journal of Managerial Issues, 17, 58-75.

Bateman, T. S., \& Organ, D. W. (1983). Job satisfaction and the good soldier: The relationship between affect and employee citizenship. Academy of Management Journal, 26, 587-595. http://dx.doi.org/10.2307/255908

Bateman, T. S., \& Snell, S. A. (2007). Management: Leading \& collaborating in a competitive world. Boston: McGraw-Hill.

Becker, B. E., Huselid, M. A., Pickus, P. S., \& Spratt, M. F. (1997). HR as a source of shareholder value: Research and recommendations. Human Resource Management, 36(1), 39-47. http://dx.doi.org/10.1002/(SICI)1099-050X(199721)36:1<39::AID-HRM8>3.0.CO;2-X

Bettencourt, L. A., \& Brown, S.W. (1997). Contact Employees: Relationship among Workplace Fairness, Job Satisfaction and Prosocial Service Behaviours. Journal of Retailing, 73(1), 39-61. http://dx.doi.org/10.1016/S0022-4359(97)90014-2

Bettencourt, L.A., Meuter, M. L., \& Gwinner, K.P. (2001). A comparison of attitude, personality, and knowledge predictors of service-oriented organizational citizenship behaviors, Journal of Applied Psychology, 86(1), 29-41. http://dx.doi.org/10.1037/0021-9010.86.1.29

Blau, P. M. (1964). Exchange and power in social life. New York: Wiley.

Brown, M. P., Sturman, M. C., \& Simmering, M. J. (2003), Compensation Policy and Organizational Performance: The Efficiency, Operational, and Financial Implications of Pay Levels and Pay Structure. Academy of Management Journal, 46(6), 752-762. http://dx.doi.org/10.2307/30040666

Buglear, J. (2005). Quantitative Methods for Business, The A-Z of QM. Burlington: Elsevier.

Byars, L., \& Rue, L. (2004). Human Resource Management. New York, McGrawHill/Irwin.

Central Bank of Malaysia. (2007). Bank Negara Malaysia Annual Report 2007. Kuala Lumpur: Jabatan Percetakan Malaysia.

Chaudhry, A. A., \& Usman, A. (2011). An Investigation of the relationship between employees' emotional intelligence and performance. African Journal of Business Management, 5(9), 3356-3562. Retrieved from http://www.academicjournals.org/article/article1380899796_Chaudhry\%20and\%20Usman.pdf

Chen, C. J., \& Huang, J. W. (2009). Strategic human resource practices and innovation performance--The mediating role of knowledge management capacity. Journal of Business Research, 62(1), 104-114. http://dx.doi.org/10.1016/j.jbusres.2007.11.016

Cherrington, D. J. (1995). The management of human resources. Englewood Cliffs, NJ: Prentice-Hall.

Chew, J., \& Chan, C. (2008). Human resource practices, organizational commitment and intention to stay. International Journal of Manpower, 29(6), 503-522. http://dx.doi.org/10.1108/01437720810904194

Coakes, S. J., \& Steed, L. G. (2003). SPSS Analysis Without Anguish Version 11.0 for Window. Australia: John Wiley \& Sons, Ltd.

Collins, C. J., \& Clark, K. D. (2003). Strategic human resource practices, top management commitment, team social networks and firm performance: the role of human resource practices in creating organizational competitive advantage. Academy of Management Journal, 46(6), 740-751. 
http://dx.doi.org/10.2307/30040665

Cummings, A., \& Oldham, G. R. (1997). Enhancing creativity: Managing work contexts for the high potential employee. California Management Review, 40, 22-38. http://dx.doi.org/10.2307/41165920

Daud, N., \& Ahmad, Z. A. (2003). Human resource management practices and business performance: An empirical study on manufacturing firms in Malaysia. Proceedings of the 5th Asian Academy of Management Conference, "Challenges of Globalized Business: The Asian Perspective", 10-13th September 2003, Kuantan, Pahang, 1, 204-209.

Davies, R. (2001). How to boost staff retention. People Management, 7, 54-56.

De Witte, H. (1999). Job insecurity and psychological well-being: Review of the literature and exploration of some unresolved issues. European Journal of Work and Organizational Psychology, 8(2), 155-177. http://dx.doi.org/10.1080/135943299398302

Delaney, J. T., \& Huselid, M. A. (1996). The impact of human resource management practices on perceptions of performance in for-profit and non-profit organizations. Academy of Management Journal, 39, 949-969. http://dx.doi.org/10.2307/256718

Delery, J. E., \& Doty, H. D. (1996). Modes of Theorizing in Strategic Human Resource Management: Tests of Universalistic, Contingency, and Configurational Performance predictions. Academy of Management Journal, 39(4), 802-35. http://dx.doi.org/10.2307/256713

Department of Statistics Malaysia. (2013). Information and Communications Services Statistics Malaysia 2012. Kuala Lumpur, Malaysia.

Dessler, G. (2008). Human Resource Management (11th ed.). New Jersey: Pearson Education.

Dyer, L., \& Reeves, T. (1995). HR strategies and form performance: what do we know and where do we need to go. International Journal of Human Resource Management, 6(3), 656-670. http://dx.doi.org/10.1080/09585199500000041

Eatough, E. M., Chang, C., Miloslavic, S. A., \& Johnson, R. E. (2011). Relationships of role stressors with organizational citizenship behavior: A meta-analysis. Journal of Applied Psychology, 96(3), 619-632. http://dx.doi.org/10.1037/a0021887

Eisenberger, R., Huntington, R., Hutchison, S., \& Sowa, D. (1986). Perceived organizational support. Journal of Applied Psychology, 71, 500-507. http://dx.doi.org/10.1037/0021-9010.71.3.500

Eisenberger, R., Stinglehaumber, F., Vandenberghe, C., Sucharski, I. L., \& Rhoades, L. (2002). Perceived supervisor support: Contributions to perceived organizational support and employee retention. Journal of Applied Psychology, 87, 565-603. http://dx.doi.org/10.1037/0021-9010.87.3.565

Feather, N. T., \& Rauter, K. A. (2004). Organizational citizenship behaviours in relation to job status, job insecurity, organizational commitment and identification, job satisfaction and work values. Journal of Occupational \& Organizational Psychology, 77(1), 81-94. http://dx.doi.org/10.1348/096317904322915928

Fey, C. F., Engström, P., \& Björkman, I. (1999). Effective human resource management practices for foreign $\begin{array}{llll}\text { firms in } & \text { Russia. }\end{array}$ http://dx.doi.org/10.1016/S0090-2616(00)80017-0

Fiorito, J., Bozeman, D., Young, A., \& Meurs, J. (2007). Organizational commitment, human resource practices, and organizational characteristics. Journal of Managerial Issues, 19(2), 186-207.

Frye, M. B. (2004). Equity Based Compensation for Employees: Firm Performance and Determinants. Journal of Financial Research, 27(1), 31-54. http://dx.doi.org/10.1111/j.1475-6803.2004.00076.x

Gong, Y., \& Chang, S. (2008). Institutional antecedents and performance consequences of employment security and career advancement practices: Evidence from the People's Republic of China. Human Resource Management, 47(1), 33-48. http://dx.doi.org/10.1002/hrm.20196

Griffin, M. A., Patterson, M. G., \& West, M. A. (2001). Job satisfaction and teamwork: the role of supervisor support. Journal of Organizational Behavior, 22(5), 537-550. http://dx.doi.org/10.1002/job.101

Guest, D. (2000). HRM: The worker's verdict. Human Resource Management Journal, 9, 5-25. http://dx.doi.org/10.1111/j.1748-8583.1999.tb00200.x

Guthrie, J. (2001). High-involvement work practices, turnover and productivity: evidence from New Zealand. Academy of Management Journal, 44, 180-192. http://dx.doi.org/10.2307/3069345 
Hair, J. F., Black, W. C., Babin, B. J., \& Anderson, R.E. (2010). Multivariate Data Analysis (7th ed.). Prentice Hall, Upper Saddle River, New Jersey.

Hammer, L. B., Kossek, E., Yragui, N. L., Bodner, T. E., \& Hanson, G. C. (2009). Development and validation of a multidimensional measure of family supportive supervisor behaviors (FSSB). Journal of Management, 35(4), 837-856. http://dx.doi.org/10.1177/0149206308328510

Harel, H. G., \& Tzafrir, S. S. (1999). The effect of human resource management practices on the perceptions of organizational and market performance of the firm. Human Resource Management, 38(3), 185-200. http://dx.doi.org/10.1002/(SICI)1099-050X(199923)38:3<185::AID-HRM2>3.0.CO;2-Y

Harman, H. H. (1976). Modern Factor Analysis. Third Edition. Chicago, USA: University of Chicago Press.

Huselid, M. A. (1995). The impact of human resource management practices on turnover, productivity and corporate financial performance. Academy of Management Journal, 38(3), 635-672. http://dx.doi.org/10.2307/256741

James, G. (2012). How to achieve true job security. Retrieved from http://www.inc.com/geoffrey-james/how-to-achieve-true-job-security.html

Jukova, M., \& Korotov, K. (1998). From a personnel department in Soviet Union to a human resource department in Russia. People and Labor, 8, 88-91. (in Russian).

Koch, M. J., \& McGrath, R. G. (1996). Improving labor productivity: Human resource management policies do $\begin{array}{lllll}\text { matter. Strategic } & \text { Management } & \text { Journal, } & \text { 335-354. }\end{array}$ http://dx.doi.org/10.1002/(SICI)1097-0266(199605)17:5<335::AID-SMJ814>3.0.CO;2-R

König, C. J., Debus, M. E., Häusler, S., Lendenmann, N., \& Kleinmann, M. (2010). Examining occupational self-efficacy, work locus of control and communication as moderators of the job insecurity-job performance relationship. Economic and Industrial Democracy, 31(2), 231-247. http://dx.doi.org/10.1177/0143831X09358629

Konovsky, M. A., \& Pugh, S. D. (1994). Citizenship behaviour and social exchange. Academy of Management Journal, 37, 656-669. http://dx.doi.org/10.2307/256704

Koon, V.-Y. (2014). Examining HRM Practices as Mediator. Journal of Strategic Human Resource Management, $3(1)$.

Kopp, M. S., Stauder, S., Purebl, G., Janszky, I., \& Skrabski, A. (2007). Work stress and mental health in a changing society. European Journal of Public Health, 18(3), 238-244. http://dx.doi.org/10.1093/eurpub/ckm077

Ladebo, O. (2004). Employees' personal motives for engaging in citizenship behavior: The case of workers in Nigeria's agriculture industry. Current Research in Social Psychology, 9(16), 220-233.

László, K. D., Pikhart, H., Kopp, M. S., Bobak, M., Pajak, A., Malyutina, S., \& Marmot, M. (2010). Job insecurity and health: A study of 16 European countries. Social Science \& Medicine, 70(6), 867-874. http://dx.doi.org/10.1016/j.socscimed.2009.11.022

Liao, H., Toya, K., Lepak, D. P., \& Hong, Y. (2009). Do they see eye to eye? Management and employee perspectives of high-performance work systems and influence processes on service quality. Journal of Applied Psychology, 94(2), 371-391. http://dx.doi.org/10.1037/a0013504

MacDuffie, J. P. (1995). Human Resource Bundles and Manufacturing Performance: Organizational Logic and Flexible Production Systems in the World Auto Industry. Industrial and Labor Relations Review, 48(2), 197-221. http://dx.doi.org/10.1177/001979399504800201

Malaysian Communications and Multimedia Commission, (MCMC). (2013). MCMC Annual Report 2012. Kuala Lumpur, Malaysia.

Malaysian Industrial Development Authority. (2013). The Services Sector in Malaysia. Retrieved from http://www.mida.gov.my/env3/uploads/events/ServicesConference22112012/Speaker1-TheServicesSectorin Malaysia.pdf

Manafi, M., Hojabri, R., \& Aghapour, A. H. (2012). The Effect of HR Practices and Leadership Style on Turnover Intention in Healthcare Industry of Iran. International Journal of Innovative Ideas, 12(3), 47-56. Retrieved from http://www.publishtopublic.com/img/upload/2037/documents/10855-39027-1-PB.pdf

Mayer, R. C., \& Gavin, M. B. (2005). Trust in management and performance: Who minds the shop while the 
employees watch the boss? Academy of Management Journal, 48, 874-888. http://dx.doi.org/10.5465/AMJ.2005.18803928

Meyer, M., Milgrom, P., \& Roberts, J. (1992). Organizational Prospects, Influence Costs, and Ownership

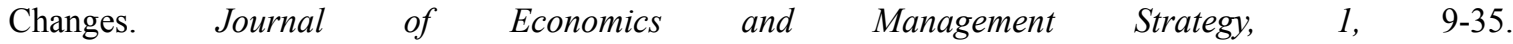
http://dx.doi.org/10.1111/j.1430-9134.1992.00009.x

Mikander, C. (2010). The Impact of a Reward System on Employee Motivation in Motonet-Espoo. (Degree Thesis, International Business, Arcada University of Applied Sciences, Finland, 1-51). Retrieved from http://www.theseus.fi/bitstream/handle/10024/16956/carolina_mikander.pdf

Moorman, R. H. (1993). The Relationship between Organizational Justice and Organizational Citizenship Behaviors: Do Fairness Perceptions Influence Employee Citizenship? Journal of Applied Psychology, 76(6), 845-855. http://dx.doi.org/10.1037/0021-9010.76.6.845

Morrison, A. M. (1996). The new leaders: Leadership diversity in America. San Francisco: Jossey-Bass.

Nasurdin, A. M., Ling, T. C., \& Fun, L. S. (2011). Service-oriented organizational citizenship behaviour: Assessing the predictive role of human resource management practices. International Journal of Arts \& Sciences, 4(9), 381-394.

Nemeth, C. J., \& Staw, B. M. (1989). The trade-offs of social control and innovation in small groups and organizations. In L. Berkowitz (Ed.), Advances in experimental social psychology, 22, 175-210. New York: Academic Press. http://dx.doi.org/10.1016/S0065-2601(08)60308-1

New Straits Times. (2015). Service sector expects growth. Retrieved from http://www.nst.com.my/news/2015/09/service-sector-expects-growth

Ogilvie, J. R. (1986). The Role of Human Resource Practices in Predicting Organizational Commitment. Group and Organization Studies, 11(4), 335-359. http://dx.doi.org/10.1177/0364108286114003

Organ, D. W. (1988). Organizational citizenship behaviour: The good soldier syndrome. USA: D.C. Heath and Company.

Organ, D. W., Podsakoff, P. M., \& Mackenzie, S. B. (2006). Organizational Citizenship Behavior. Its Nature, Antecedents, and Consequences. Sage Publication: Thousands Oaks.

Paine, J. B., \& D. W. Organ. (2000). The cultural matrix of organizational citizenship behaviour: Some preliminary conceptual and empirical observations. Human Resource Management Review, 10(1), 45-49. http://dx.doi.org/10.1016/S1053-4822(99)00038-8

Parker, O., \& Wright, L. (2001). Pay and employee commitment: the missing link. In Ivey Business Journal, 65(3), $70-79$.

Pfeffer, J. (1998). Seven practices of successful organizations. California Management Review, 40(2), 96-124. http://dx.doi.org/10.2307/41165935

Podsakoff, P. M., MacKenzie, S. B., Moorman, R. H., \& Fetter, R. (1990). Transformational leader behaviors and their effects on followers' trust in leader, satisfaction, and organizational citizenship behaviors. Leadership Quarterly, 1, 107-142. http://dx.doi.org/10.1016/1048-9843(90)90009-7

Podsakoff, P. M., MacKenzie, S. B., Paine, J. B., \& Bachrach, D. G. (2000), Organizational citizenship behaviors: A critical review of the theoretical and empirical literature and suggestions for future research. Journal of Management, 26(3), 513-563. http://dx.doi.org/10.1177/014920630002600307

Ramsay, H., Scholarios, D., \& Harley, B. (2000). Employees and high-performance work systems: Testing inside the black box. British Journal of Industrial Relations, 38(4), 501-531. http://dx.doi.org/10.1111/1467-8543.00178

Reisel, W. D., Probst, T. M., Chia, S., Maloles, C. M., \& König, C. J. (2010). The effects of job insecurity on job satisfaction, organizational citizenship behavior, deviant behavior and negative emotions of employees. International Studies of Management and Organization, 40(1), 74-91. http://dx.doi.org/10.2753/IMO0020-8825400105

Rhoades, L., Eisenberger, R., \& Armeli, S. (2001). Affective commitment to the organization: The contribution of perceived organizational support. Journal of Applied Psychology, 86, 825-836. http://dx.doi.org/10.1037/0021-9010.86.5.825

Rose, R. C., \& Kumar, N. (2006). The influence of organizational and human resource management strategies on 
performance. Performance Improvement, 45(4), 18-24. http://dx.doi.org/10.1002/pfi.2006.4930450406

Rousseau, D. M., \& Greller, M. M. (1994). Human resource practices: Administrative contract makers. Human Resource Management, 33, 385-401. http://dx.doi.org/10.1002/hrm.3930330308

Salanova, M., Agut, S., \& Peiró, J. M. (2005). Linking organizational resources and work engagement to employee performance and customer loyalty: The mediation of service climate. Journal of Applied Psychology, 90, 1217-1227. http://dx.doi.org/10.1037/0021-9010.90.6.1217

Schneider, B., \& Bowen, D. (1985). Employee and customer perceptions of service in banks: Replication and extension. Journal of Applied Psychology, 70, 423-433. http://dx.doi.org/10.1037/0021-9010.70.3.423

Sekaran. (2011). Research method for business: A skill building approach (5th ed.). John Wiley.

Shahzad, K., Bashir, S., \& Ramay, M. I. (2008). Impact of HRM practices on perceived performance of university teachers in Pakistan. International review of business research papers, 4(2), 302-315. Retrieved from http://irbrp.com/static/documents/March/2008/1423379665.pdf

Shekshnia, S. (1998). Western multinationals' human resource practices in Russia. European Management Journal, 16, 460-465. http://dx.doi.org/10.1016/S0263-2373(98)00022-X

Simon. (2011). What is job security (and does it really exist?). Retrieved from http://www.simonst.apleton.com/wordpress/2011/02/12/what-is-job-security-and-does-it-really-exist/

Simosi, M. (2010). The role of social socialization tactics in the relationship between socialization content and newcomer's affective commitment. Journal of Managerial Psychology, 25, 301-327. http://dx.doi.org/10.1108/02683941011023758

Snape, E., \& Redman, T. (2010). HRM Practices, Organizational Citizenship Behaviour, and Performance: A Multi-Level Analysis. Journal of Management Studies, 47, 1219-1247. http://dx.doi.org/10.1111/j.1467-6486.2009.00911.x

Staufenbiel, T., \& König, C. J. (2010). A model for the effects of job insecurity on performance, turnover intention, and absenteeism. Journal of Occupational and Organizational Psychology, 83(1), 101-117. http://dx.doi.org/10.1348/096317908X401912

Sun, L. Y., Aryee, S., \& Law, K. S. (2007). High-performance human resource practices, citizenship behavior, and organizational performance: A relational perspective. The Academy of Management Journal Archive, 50(3), 558-577. http://dx.doi.org/10.5465/AMJ.2007.25525821

Sun, L., \& Pan, W. (2008). HR Practices Perceptions, Emotional Exhaustion, and Work Outcomes: A Conservation of Resources Theory in the Chinese Context. Human Resource Development Quarterly, 14, 55-73. http://dx.doi.org/10.1002/hrdq. 1225

Susan. (2016). Employment Contract, You Can Negotiate Fair Employment Contracts. Retrieved from http://humanresources.about.com/od/glossarye/g/employment_contract.htm

Tang, T. W., \& Tang, Y. Y. (2012). Promoting service-oriented organizational citizenship behaviors in hotels: The role of high-performance human resource practices and organizational social climates. International Journal of Hospitality Management, 31(3), 885-895. http://dx.doi.org/10.1016/j.ijhm.2011.10.007

Terpstra, D. E., \& Rozell, E. J. (1993). The relationship of staffing practices to organizational level measures of performance. Personnel Psychology, 46, 27-48. http://dx.doi.org/10.1111/j.1744-6570.1993.tb00866.x

Tessema, M. T., \& Soeters, J. L. (2006). Challenges and Prospects of HRM in Developing Countries: Testing the HRM-Performance Link in the Eritrean Civil Service. International Journal Human Resource Management, 17(1), 86-105. http://dx.doi.org/10.1080/09585190500366532

The Star. (2014). Malaysia's services sector to contribute more to economy. Retrieved from http://www.thestar.com.my/business/business-news/2014/08/18/malaysias-services-sector-to-contribute-mor e-to-economy/

Tsaur, S. H., \& Lin, Y. C. (2004). Promoting service quality in tourist hotels: The role of HRM practices and service behavior. Tourism Management, 25(4), 471-481. http://dx.doi.org/10.1016/S0261-5177(03)00117-1

Tsui, A. S., Pearce, J. L., Porter, L. W., \& Tripoli, A. M. (1997). Alternative approaches to the employee-organization relationship: Does investment pay off? Academy of Management Journal, 40, 1089-1121. http://dx.doi.org/10.2307/256928

Turnipseed, D. L., \& Murkison, E. (1993). Cultural comparison of organization citizenship behaviour: Does the 
OCB phenomenon transcend national culture? International Journal of Organizational Analysis, 8(2), 200-222. http://dx.doi.org/10.1108/eb028917

United States Department of Labor. (1993). High Performance Work Practices and Firm Performance. Washington, DC: US Dept. Labor.

Van Maanen, J., \& Schein, E. H. (1979). Toward a Theory of Organizational Socialization. In B. M. Staw (Ed.), Research in Organizational Behavior. JAI Press, Greenwich, CT., USA, 209-264.

Van Scotter, J. R. (2000). Relationships of task performance and contextual performance with turnover, job satisfaction, and affective commitment. Human Resource Management Review, 10(1), 79-95. http://dx.doi.org/10.1016/S1053-4822(99)00040-6

Vroom, V. H. (1964). Work and motivation. New York: Wiley.

Walz, S. M., \& Niehoff, B. P. (2000). Organizational Citizenship Behaviors: Their Relationship to Organizational Effectiveness. Journal of Hospitality and Tourism Research, 24(3), 108-26. http://dx.doi.org/10.1177/109634800002400301

Wentland, D. M. (2003). A new practical guide for determining expatriate compensation: the comprehensive model. Compensation and Benefits Review, 35(3), 45-50. http://dx.doi.org/10.1177/0886368703035003006

Werner, \& Eleanor. (1993). Developing and using questionnaires. Retrieved from http://archive.gao.gov/t2pbat4/150366.pdf

Whitener, E. (2001). Do high commitment human resource practices affect employee commitment? A cross-level analysis using hierarchical linear modeling, Journal of Management, 27(5), 515-535. http://dx.doi.org/10.1177/014920630102700502

Wick, C., \& Leon, L. (1993). The Learning Edge: How Smart Managers and Smart Companies Stay Ahead. McGraw Hill, New York.

Wong, Y., Wong, C., Ngo, H., \& Lui, H. (2005). Different responses to job insecurity of Chinese workers in joint ventures and state-owned enterprises. Human Relations, 58(11), 1391-1418. http://dx.doi.org/10.1177/0018726705060243

Wright, P. M., Gardner, T. M., \& Moynihan, L. M. (2003). The impact of HR practices on the performance of business units. Human Resource Management Journal, 13(3), 21-36. http://dx.doi.org/10.1111/j.1748-8583.2003.tb00096.x

Yeh, C. M. (2013). Tourism involvement, work engagement and job satisfaction among frontline hotel employees. Annals of Tourism Research, 42, 214-239. http://dx.doi.org/10.1016/j.annals.2013.02.002

Yen, H., \& Niehoff, B. (2004). Organizational Citizenship Behaviors and Organizational Effectiveness: Examining Relationships in Taiwanese Banks. Journal of Applied Social Psychology, 34(8), 1617-1637. http://dx.doi.org/10.1111/j.1559-1816.2004.tb02790.x

Zerbe, W. J., D. Dobni, \& G. H. Harel. (1998). Promoting Employee Service Behaviour: The Role of Perceptions of Human Resource Management Practices and Service Culture. Canadian Journal of Administrative Science. http://dx.doi.org/10.1111/j.1936-4490.1998.tb00160.x

Zeytinoglu, I. U., Denton, M., Davies, S., \& Plenderleith Millen, J. (2009). Casualized employment and turnover intention: Home care workers in Ontario. Canada. Health Policy, 91, 258-268. http://dx.doi.org/10.1016/j.healthpol.2008.12.004

\section{Copyrights}

Copyright for this article is retained by the author(s), with first publication rights granted to the journal.

This is an open-access article distributed under the terms and conditions of the Creative Commons Attribution license (http://creativecommons.org/licenses/by/4.0/). 